\title{
The Effect of Institutional Ownership, Managerial Ownership and Leverage on Company Value in Subsectors Property and Real Estate Listed in Indonesia Stock Exchange for 2016-2018
}

\author{
Rizki Cahyo Nugroho \\ Mercu Buana University, Jakarta, Indonesia
}

\begin{abstract}
This study aims to examine the effect of Institutional Ownership, Managerial Ownership, and Leverage on Company Value in property and real estate sector companies listed on the Indonesia Stock Exchange (BEI) in 2016-2018. This research uses a quantitative approach, with a type of explanatory research. From 48 existing companies, acquired as many as 23 companies that meet criteria specified sampling. The sample method in this study using nonprobability sampling method with the sampling technique using purposive sampling. The results in this study indicate that institutional ownership is proven to have a significant positive effect on Company Value in the Property \& Real Estate sub-sector companies in 2016-2018. Managerial Ownership has a significant positive effect on Company Value in the Property \& Real Estate subsector companies in 2016-2018. Leverage is proven to have a significant positive effect on Company Value in the Property \& Real Estate subsector companies in 2016-2018.
\end{abstract}

Keywords:- Institutional Ownership (KPI), managerial ownership (KPM), Leverage (DER), Company Value.

\section{INTRODUCTION}

High interest of investors in investing capital in the capital market not only aims in the short term but also aims to earn income in the long term. Before investing, investors certainly need to collect information as one of the basic considerations in making investment decisions in the capital market. The main consideration is to see the company's performance is good or bad or by looking at the high and low value of the company.

Certainly with high corporate value makes investors believe in future prospects that are generally seen in rising share prices that will provide prosperity to shareholders or investors. The growth in the value of property and real estate subsector companies decreased in 2018, in contrast to the construction sub-sector which increased in 2018.
Hakiman, Dr., MM

Mercu Buana University, Jakarta, Indonesia

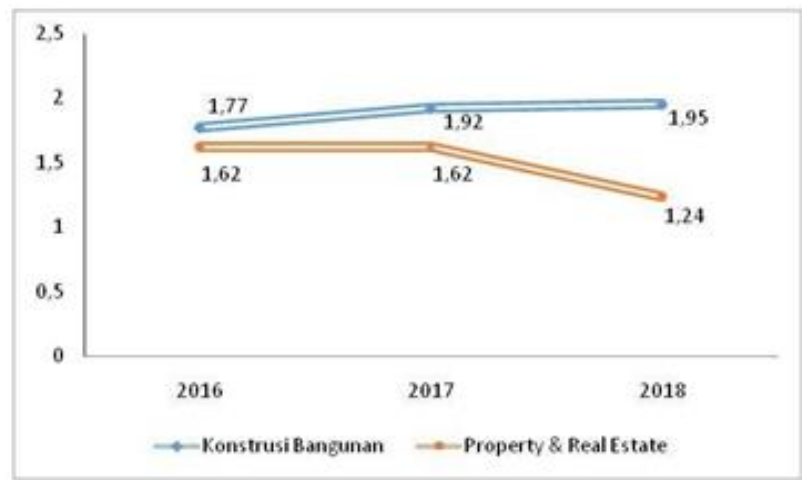

Fig 1:- Growth of Company Value (PBV) in Building Construction Subsector vs Subsector Property \& Real

Estate (Source: Indonesia Stock Exchange)

Based on PBV in the property \& real estate subsector, it was below the value of the building construction sub-sector company during the period 2016 to 2018. The property \& real estate subsector continued to decline, until 2018 to be the most significant decrease compared to other years. Meanwhile, the decline that occurred in 2017 was due to the low purchasing power of the public in the property and real estate sub-sector, reflected in a survey conducted by Bank Indonesia (BI) regarding the Consumer Confidence Index (IKK) June 2017 of 122.4 or a decrease of 3.5 points if compared to the IKK in the previous month.

\section{LITERATURE}

\section{A. Agency Theory}

Jensen (1976) explain the agency relationship in agency theory that a company is a collection of contracts (nexus of contract) between the owner of economic resources (principal) and the manager (agent) who manages the use and control of these resources.. Kusumawati (2019) revealed that the problem of agency arises because of information inequality that requires the completion of internal mechanisms of action, a form of ownership can be the solution to the problem of agency

\section{B. Signaling Theory}

Signal theory was discovered by Michael Spence (1973). This theory involves two parties, namely insiders such as management who play a role in providing signals and outsiders such as investors who play a role in receiving these signals. Kusumawati (2019) stated that signaling 
theory is rooted in pragmatic accounting theory that focuses on the influence of information on changes in information user behavior.Information published as an announcement will signal for investors in investment decision making

\section{Company Value}

According to Fama (1978), company value can be seen from its share price. Share prices are formed at the request and supply of investors, so that the share price can be used as a proxy for company value. Lestari (2017) The value of the company is the investor's perception of the success rate of the company which is often associated with the share price.

\section{Institutional Ownership}

Porter (1992) Institutional ownership is ownership of shares by other institutions, namely ownership by companies or other institutions Claudia (2013) reveal that institutional ownership is ownership of company shares owned by institutions or institutions such as insurance companies, banks, investment companies, and other institutional ownership.

\section{E. Managerial Ownership}

According to Downes (1999) Managerial Ownership the shareholders which also means in this case as owners in the company from the party management who actively participate in making decisions in a company concerned.

Sintyawati (2018) Managerial ownership represents a large percentage of the shareholding by the management. Managerial ownership is measured by using the ratio between the number of shares owned by managers (managers and directors) to the total shares outstanding in the company namely.

\section{F. Leverage}

By using leverage, companies can not only gain profits but also cause the company to experience losses, because financial leverage means that the company imposes risks on shareholders, thereby affecting stock returns (Weston 1999). Andam (2019) Debt to Equity Ratio (DER) is a financial ratio indicating the relative proportion of shareholders' equity and debt used to finance a company's assets.

\section{G. Thinking Framework}

This research framework is based on research and represents several theories and estimates the effect of the independent variable on the dependent. The framework can be explained as follows.

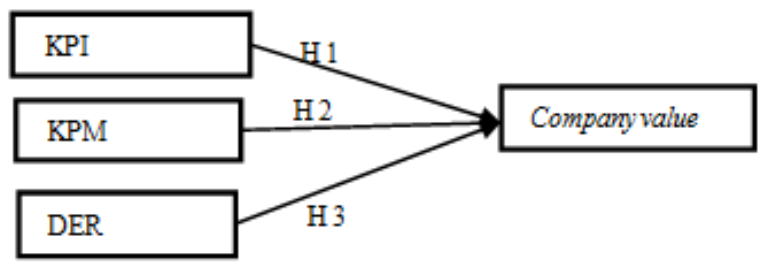

\section{RESEARCH METHODS}

This research is a quantitative study using the Causality method. The population of this study is Property and Real Estate Company listed on the Indonesia Stock Exchange from 2016 to 2018, totaling 48 companies. The number of samples in this study were 23 companies using purposive sampling. The measurement scale used is the ratio scale and nominal scale.

The analysis method used in this research is multiple regression analysis with panel data analysis model which aims to determine how much influence Institutional Ownership, Managerial Ownership and Leverage on Company Value. The panel data regression equation in this study is as follows:

$$
\mathrm{Y}=\alpha+\beta 1 X 1+\beta 2 X 2+\beta 3 X 3
$$

\section{RESULTS AND DISCUSSION}

\section{A. Descriptive Analysis}

\begin{tabular}{|l|c|c|c|c|}
\hline Variabel & Minimum & Maximum & Mean & Std. Dev. \\
\hline KPI & 0.113555 & 0.964421 & 0.628860 & 0.218404 \\
\hline KPM & 0.000000 & 0.480208 & 0.084947 & 0.119616 \\
\hline DER & 0.034458 & 3.093590 & 0.726339 & 0.632743 \\
\hline PBV & 0.000000 & 8.297678 & 1.519627 & 2.005008 \\
\hline
\end{tabular}

Table 1:- Descriptive Statistics Test Results

(Source: Indonesia Stock Exchange)

The Institutional Ownership Variable during 2016 2018 obtained the lowest Institutional Ownership value of 0.113555 and the highest was 0.964421 with a mean value of 0.628860 and resulted in a value standard deviation of 0.218404 .

$>$ The Managerial Ownership Variable during the 2016 2018 period obtained the lowest Managerial Ownership value of 0.000000 and the highest Managerial Ownership of 0.480208 . So that it gets a mean value of 0.084947 and a standard deviation of 0.19616 .

$>$ The variable Leverage during 2016 - 2018 obtained a minimum value of 0.034458 and a maximum of 3.093590 resulting in a mean of 0.726339 and a standard deviation of 0.632743 .

$>$ The Company Value Variable during 2016 - 2018 obtained a minimum value of 0.000000 and a maximum of 8.297678 resulting in a mean value of 1.519627 and a standard deviation of 2.005008 .

\section{B. Analysis Regression Data Panel}

> Panel Data Regression Equations

Dependent Variable: PBV Method: Panel Least Squares

Date: 08/13/20 Time: 09:56 Sample: 20162018

Periods included: 3

Cross-sections included: 23

Total panel (balanced) observations: 69

Fig 2:- Theoretical Framework 
ISSN No:-2456-2165

\begin{tabular}{|crrrr|}
\hline \multicolumn{1}{|c}{ Variable } & Coefficient & Std. Error & t-Statistic & Prob. \\
\hline \hline C & -3.562496 & 0.610175 & -5.838481 & 0.0000 \\
KPI & 3.817444 & 0.663705 & 5.751721 & 0.0000 \\
KPM & 3.215560 & 1.203958 & 2.670824 & 0.0106 \\
DER & 3.315710 & 0.685214 & 4.838939 & 0.0000 \\
\hline \hline \multicolumn{5}{c}{ Effects Specification } \\
\hline \hline Cross-section fixed (dummy variables) & & \\
\hline \hline R-squared & 0.942833 & Mean dependent var & 1.519627 \\
Adjusted R-squared & 0.909597 & S.D. dependent var & 2.005008 \\
S.E. of regression & 0.602848 & Akaike info criterion & 2.106415 \\
Sum squared resid & 15.62733 & Schwarz criterion & 2.948252 \\
Log likelihood & -46.67131 & Hannan-Quinn criter. & 2.440400 \\
F-statistic & 28.36741 & Durbin-Watson stat & 3.069396 \\
Prob(F-statistic) & 0.000000 & & \\
\hline \hline
\end{tabular}

Table 2:- Fixed Model Data Regression Results

\section{$P B V=-3.562496+3,817444 \mathrm{KPI}+3,215560 \mathrm{KPM}+$ 3.315710 DER}

\section{F Test Result}

The results of the F test can be seen in the table 4. By looking at the F-statistic and Prob (F-statistic) it can be explained that the probability value of 0.0000 is smaller $(<)$ than 0.05 , that is, this shows that the variables of Institutional Ownership, Managerial Ownership dan Leverage are simultaneously has a significant effect on the Company Value.

\section{$t$ Test Result}

If the $t$ value of the estimated parameter is greater than the t-table value, then partially the independent variable affects the dependent variable. The results of the $t$ test (partial regression test) can be seen in Table 4. By looking at the t- Statistic and Probability column, it can be explained

- The estimate obtained was 3.817444 , with a t-statistic value of 5.751721 and a p-value of $0.0000<0.05$ (error rate $\alpha=5 \%$ ), then the first hypothesis was accepted. It can be concluded that Institutional Ownership has a positive effect on Company Value in thesub-sector companies property and real estate listed on the Indonesia Stock Exchange.

- The estimate obtained was 3.215560, with a t-statistic value of 2.670824 and a p-value of $0.0106<0.05$ (error rate $\alpha=5 \%$ ), then the second hypothesis was accepted. It can be concluded that Managerial Ownership has a positive effect on Company Value insub-sector companies property and real estate listed on the Indonesia Stock Exchange.

- The value estimated is 3.315710, with a t-statistic value of 4.838939 and a p-value of $0.0000<0.05$ (error rate $\alpha$ $=5 \%$ ), the third hypothesis is accepted. It can be concluded that leverage has a positive effect on company value.
The results of the regression show that Institutional Ownership (KPIs), Menajrial Ownership (KPM), and Leverage (DER) have a positive effect on the Value of the Company (PBV).

\section{Determination Coefficient Test}

Based on the results of data processing, the Adjusted R- Squared value is 0.909597. This means that the independent variables in this study, namely Institutional Ownership (KPI), Menajrial Ownership (KPM), and Leverage (DER) together can explain the dependent variable, namely the company value of $90.95 \%$. the remaining $9 \%$ is explained by other variables outside the research model.

\section{Discussion}

The Institutional Ownership has a positive influence on Company Value in the property and real estate subsector listed on the Indonesia Stock Exchange 20162018. The test results show that the hypothesis is accepted. This shows that institutional ownership is proven to have a positive influence on corporate value in the property and real estate sub-sector companies in 2016 - 2018. Jensen (1976) states that institutional ownership has a very important role in minimizing agency conflicts that occur between managers and shareholders. With share ownership in this group, financial management and the direction of company policy will certainly get full control or full attention from shareholders before deciding on a company policy. The results of this study are in line with the findings of previous research conducted by Lestari (2017); Ngatemin (2018); Widyaningsih (2018); Asnawi. (2019). the better the proportion of institutional ownership, the better the value of the company which in turn will have a positive impact on the prosperity of shareholders. 
The Managerial Ownership has a positive influence on Company Value in the Subsector Companies Property and Real Estate listed on the Indonesia Stock Exchange 2016-2018. The test results show that the hypothesis is accepted. The results of this study support the agency theory of Jensen (1976) which explains management as an agent who is trusted by shareholders or principals to manage the company in order to achieve the goal of welfare of the principal. Management will act as an agent as well as a principal so that they will have the same goals. Management will be more careful in making decisions because management will accept the consequences of making decisions made. The results of this study support Vintila (2015)..

> The Leverage has a positive effect on Company Value in thesub-sector property and real estate listed on the Indonesia Stock Exchange 2016-2018. The test results show that the hypothesis is accepted. DER is also often used as a measure in analyzing financial statements to show the amount of collateral available to Famiah's creditors (2018). According to the signaling theory, the amount of capital the company has from the debt it receives, it is considered that company investors have many opportunities to use their capital in expanding or developing business. The more the company develops, the greater the profits for investors, so that investors are more interested in buying company shares. The results of the hypothesis support the research conducted by Devianasari (2015); Simangunsong 2018); Kahfi (2018).

\section{CONCLUSIONS \& SUGGESTION}

\section{A. Conclusions}

Based on the results of the research that has been done, it can be concluded as follows:

$>$ Instritusional ownership has proven to have a positive and significant effect on the Company's Value on Property and Real estate companies listed on the Indonesia Stock Exchange in 2016- 2018.

> Managerial Ownership has a positive and significant impact on the Company's Value in Property and Real estate companies listed on the Indonesia Stock Exchange in 2016-2018.

$>$ Leverage has proven to have a positive and significant effect on the Company's Value on Property and Real estate companies listed on the Indonesia Stock Exchange in 2016-2018.

$>$ Institutional Ownership, Managerial Ownership and Leverage together have a positive and significant effect on the Company's Value in Property \& Real estate companies listed in IDX in 2016 - 2018. The amount of influence exerted together amounted to $90.95 \%$.

\section{B. Suggestion}

Based on the results and conclusion of research, advice can be made for companies, investors and subsequent research as follows:

\section{For The Company}

Institutional ownership has a significant positive effect on company value. The greater the value of institutional ownership, the stronger the control over the company so that company owners can control management behavior in order to act in accordance with company goals which in turn will increase company value. Apart from institutional ownership, companies can use debt as a more reliable signal to investors. This is because companies that increase debt can be seen as companies that are confident about the company's prospects in the future. In addition, managerial ownership also has a significant positive effect on company value, therefore the company is expected to increase management ownership which aims to reduce agency problems.

\section{For Investors}

Investors are encouraged to review first the information published by the company that will guide investment decisions. Investors can consider components of share ownership such as institutional ownership or managerial ownership. That way investors can assess which companies have potential agency problems so that they have an impact on company performance. Apart from that, investors must also look at the company's capital structure. With this, investors can have a signal about the company's future goals.

\section{Share Further Research}

The results showed that Institutional Ownership, Managerial Ownership and Leverage together have an effect on Company Value by $90.95 \%$. So that in order to increase Company Value in thesub-sector Property \& Real Estate, it is suggested for further research to add other variables which are expected to affect Company Value. In addition, this research is also in line with agency theory and signaling theory, so for further research it is recommended to try to take other industrial research objects of companies.

\section{REFERENCES}

[1]. Anjani T \& Syarif AD 2019, "The Effect of Fundamental Analysis on Stock Returns using Data Panels; Evidence Pharmaceutical Companies listed on IDX', International Journal of Innovative Science and Research Technology Vol 4 No.7.

[2]. Asnawi, Ibrahim, R, Saputra, M 2019, 'Pengaruh Kepemilikan Manajerial, Kepemilikan Institusional dan Kebijakan Hutang Terhadap Nilai Perusahaan (Studi Pada Perusahaan Manufaktur Yang Terdaftar Di Bursa Efek Indonesia)', Jurnal Perspektif Ekonomi Darussalam. Vol. 5, No. 1, pp. 72-85. 
[3]. Claudia, W, \& Ekadjaja A 2013, 'Pengaruh Kepemilikan Manajerial, Kepemilikan Institusional, Keputusan Investasi, Keputusan Pendanaan, dan Profitabilitas Terhadap Nilai Perusahaan', Jurnal Akuntansi. Vol. 13, No. 2, pp. 929-944.

[4]. Devianasari, NL, \& Suryantini, NP 2015, 'Pengaruh Price Earning Ratio, Debt To Equity Ratio, dan Dividen Payout Ratio Terhadap Nilai Perusahaan Pada Perusahaan Manufaktur Yang Terdaftar Di Bursa Efek Indonesia', E-Jurnal Manajemen Unud, Vol. 4, No. 11, hal. 3646-3674.

[5]. E. Porter, Michael, (1993). "Competitive Advantage: Creating and Maintaining Superior Performance", PT. Gramedia, Jakarta.

[6]. Fama, Eugene F. 1978. "The Effect of a Company Investment and Financing Decisison on the Welfare of its Security Holders". American Economic Review : Vol. 68 PP.271-282.

[7]. Hasibuan, V, Dzulkirom, M, \& Endang, W 2016, Pengaruh Leverage dan Profitabilitas terhadap Nilai Perusahaan (Studi pada Perusahaan Property dan Real Estate yang Terdaftar di Bursa Efek Indonesia Periode Tahun 2012-2015), Jurnal Administrasi Bisnis (JAB). Vol. 39, No. 1, pp. 139-147.

[8]. Jensen, M. C and Meckling, W.H. 1976. 'Theory of the Company: Managerial Behavior, Agency Costs and Ownership Structure . Journal of Financial Economics, Oktober, 1976, V. 3, No. 4, pp. 305-360.

[9]. John Downes, Jordan Elliot Goodman. 1999. Dictionary Of Finance And Investment Terms.

[10]. Kahfi, MF, Pratomo, D, \& Aminah, W 2018, 'Pengaruh Current Ratio, Debt To Equity Ratio, Total Assets Turnover Dan Return On Equity Terhadap Nilai Perusahaan (Studi Kasus Pada Perusahaan Manufaktur Sektor Food and Beverage Yang Terdaftar Di Bursa Efek Indonesia Pada Tahun 2011 2016)', e-Proceeding of Management, Vol. 5, No. 1, hal. 566-574.

[11]. Kusumawati, E \& Setiawan, A 2019, 'The Effect of Managerial Ownership, Institutional Ownership, Company Growth, Liquidity, and Profitability on Company Value', Jurnal Riset Akuntansi dan Keuangan Indonesia, pp. 136-146.

[12]. Lestari 2017, 'Pengaruh Kepemilikan Institusional dan Struktur Modal Terhadap Nilai Perusahaan', Jurnal Riset Manajemen dan Bisnis (JRMB) Fakultas Ekonomi UNIAT, Vol. 2, pp. 293-306.

[13]. Ngatemin, Maksum, A, Erlina \& Sirojuzilam 2018, 'Effects Of Institutional Ownership and Profitability to Company Value With The Capital Structure as Intervening Variable (Empirical Study at Company Tourism Industry Sector Listed In Indonesia), International Journal of Civil Engineering and Technology, Vol. 9, Issue. 5, pp. 1305-1320.

[14]. Simangunsong, ES, Karamoy, H, Pusung, RJ 2018, 'Pengaruh Struktur Modal dan Kepemilikan Institusional Terhadap Nilai Perusahaan pada Perusahaan Konstruksi yang Terdaftar di Bursa Efek Indonesia', Jurnal Riset Akuntansi Going Concern, Vol. 13, No. 2, pp. 538-547.
[15]. Spence, Michael. 1973. Job Market Signaling. The Quarterly Journal of Economics, Vol. 87, No. 3. (Aug., 1973), pp. 355-374.

[16]. Vintilă, G \& Gherghina, SC 2015, 'Does Ownership Structure Influence Company Value? An Empirical Research towards the Bucharest Stock Exchange Listed Companies,' International Journal of Economics and Financial, Vol. 5, No. 2, pp. 501-514.

[17]. Widyaningsih, D 2018, 'Kepemilikan Manajerial, Kepemilikan Institusional, Komisaris Independen, Serta Komite Audit Pada Nilai Perusahaan Dengan Pengungkapan CSR sebagai Variabel Moderating dan Company Size sebagai Variabel Kontrol', Jurnal Akuntansi dan Pajak, Vol. 19, No. 1, hal. 38-52. 